JAMP: Jurnal Adminitrasi dan Manajemen Pendidikan

Volume 4 Nomor 4 Desember 2021, Hal : 307 - 319

Tersedia Online di http://journal2.um.ac.id/index.php/jamp/

ISSN 2615-8574 (online)

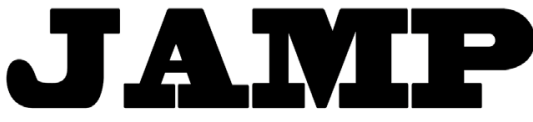

JURNAL ADMINISTRASI DAN MANAJEMEN PENDIDIKAN

\title{
ORGANIZATIONAL LEARNING, ACADEMIC SUPERVISION, AND WORK MOTIVATION IN ENHANCING TEACHING COMPETENCE AND TEACHER PERFORMANCE IN MODERN PESANTREN
}

\author{
Abdu Alifah, Anggraini Sukmawati \\ Department of Management, Faculty of Economics and Management, IPB University, Bogor \\ Jl. Raya Dramaga Kampus IPB Dramaga Bogor \\ E-mail: abdualifahalifah@apps.ipb.ac.id
}

\begin{abstract}
Teaching competence and teacher performance are determinant issues in Islamic educational institutions to date, including modern pesantren. Therefore, this study attempted to analyze the effect of organizational learning, academic supervision, and work motivation that possibly enhance teaching competence and teacher performance which has been rarely studied, especially in pesantren. This study involved 128 teachers at modern pesantren Ummul Quro Al-Islami Bogor selected through a simple random sampling method. The collected data were analyzed using Structural Equation Modeling-Partial Least Square (SEM-PLS). The results found that teaching competence positively and significantly affected teacher performance in modern pesantren. Furthermore, organizational learning was also found to positively and significantly affect teaching competence and teacher performance. Meanwhile, academic supervision and work motivation positively and significantly affected teaching competence, but insignificantly affected teacher performance. This study also examined the indirect effect and found that organizational learning, academic supervision, and work motivation positively and significantly affected teacher performance in modern pesantren mediated by teaching competencies. Thus, modern pesantren can effectively enhance their teachers' performance by increasing organizational learning, academic supervision, and work motivation through the mediation of teaching competencies.
\end{abstract}

Keywords: organizational learning; academic supervision; work motivation; teaching competence; teacher performance.

the teacher is a determinant factor in enhancing the quality of educational institutions (Mailool et al., 2020; Hutagalung et al., 2020; Lie et al., 2020; Hartiwi, Kozlova and Masitoh, 2020; Mesiono, 2019; Nasution, 2018), including pesantren (Rahmah et al., 2020; Rahman et al., 2019; Kartini, Sujanto and Mukhtar, 2017). Therefore, improving teacher performance is crucial for pesantren to compete with other educational institutions in general. Otherwise, issue related to teacher performance has been interesting to be explored, regardless it's not a novelty in educational studies (Good and Lavigne, 2015) since numerous studies were conducted (Measures, 2016) (Falout, 2010). However, teacher performance is still essential to be studied since education demand has continuously been developing and changing (Mailool et al., 2020; Goodwin and Slotnik, 2019; Steinberg and Kraft, 2017).

Teachers with a good level of performance can increase learning effectiveness and quality (Rahmah et al., 2020; Nasution, 2018). Lie et al., (2020) and Hartiwi, Kozlova and Masitoh (2020) stated that teacher performance is viewed through four competencies, i.e., pedagogic, personality, social, and professional competencies. Ideally, in the process of learning, teachers are supposed to have these competencies despite the fact that most educational institutions in Indonesia, including pesantren, suffered some issues related to the low quality of teacher performance (Kartini, Sujanto and Mukhtar, 2017). Furthermore, Muhammadi, Marzuki and Hussin (2015) categorized teachers in Islamic educational institutions into; first, less qualified teachers or under qualifications; second, decent teachers, but not in accordance with their educational background; and last, teachers with qualifications and backgrounds that comply with 
government regulations. According to Muhammadi, Marzuki and Hussin (2015), 60 percent of teachers are under qualifications based on government regulations, and more than 80 percent of them are teachers in madrasah, in which pesantren are included.

A study by Murtiningsih, Kristiawan and Lian (2019), Andriani, Kesumawati and Kristiawan (2018) and Renata, Wardiah and Kristiawan (2018) found several indicators that showed teachers' low performance, including teachers' low commitment to educating and teaching, professions undertaken, as well as improving their professional abilities. Verawati (2016) viewed teachers' low performance through their incapability to compile lesson plans, disorganized time management, poor interactions with students, and incompetence in mentoring students. In the context of pesantren, Kartini, Sujanto and Mukhtar (2017) argued that weak unfuntioned human resources development, which is indicated by less qualified teachers, poor competencies and insufficient teacher services and facilities, is one of the determinant factors that caused teachers' low performance.

Besides, as the oldest educational institution in Indonesia, the educational system in pesantren is broadly divided into two models, i.e., salafiyah/traditional pesantren and khalafiyah/modern pesantren (Yahya, 2015). In this study, the authors focused on exploring teacher performance in modern pesantren, considering that modern pesantren is the most complex model among the others since its educational systems integrated formal and non-formal curricula (Makruf, 2017), so that teacher with a high level of performance is required. One of the modern pesantren that showed rapid development is Ummul Quro AlIslami Bogor (PM UQI). Based on data from the Directorate of Islamic Education-Ministry of Religious Affairs (2020), PM UQI is the most populous pesantren in Bogor with 3948 students. Therefore, the quality of pesantren education must be in accordance with the increase in students' number.

According to the study conducted by Ulfaa and Irawan (2018), several teachers at PM UQI taught the subject not in accordance with their educational background, while the others were under qualification since they did not possess a bachelor's degree. The authors also conducted the preliminary study by interviewing the head of the pesantren education bureau and found that several teachers were undisciplined in establishing their teaching activities. For instance, teacher performance appraisal at PM UQI is conducted through their attendance and lateness in class measured by a score reduction system (the starting score is 100). Data from the pesantren education bureau showed that of 252 teachers, 9 of them are teachers with scores of less than 50,97 are less than 100 scores, and 146 successfully maintain 100 scores for the first semester of 2020. However, this point is alleged to continuously decrease until the end of the second semester if most of them are undisciplined in conducting teaching activities.

Previous studies found that teacher performance is strongly affected by teaching competence, consisted of pedagogical, professional, social, and personality competencies (Nurhasni et al., 2020; Aji, Martono and Fakhruddin, 2019; Toha and Katoningsih, 2018; Sumantri and Whardani, 2017). For instance, Purba, Rafiani and Ali (2018) examined the effect of teaching competence, organizational commitment and non-financial compensation on teacher performance and found that teaching competence was the most determinant variable in enhancing teacher performance. In addition, several other studies showed that teaching competence is further positively affected by organizational learning, academic supervision, and teachers' work motivation. Hartono et al., (2017) found that organizational learning positively affected teaching competence in teachers through indicators of learning proactively, finding alternative methods, learning new knowledge, discussing the current issues and trying a different perspective on teaching. Meanwhile, Saihu (2020), Azwardi (2020) and Huda (2018) found that academic supervision is a determinant factor in improving teaching competence through a directive, collaborative, and instructive approach. Et last, Pradja et al., (2018) and Boset, Asmawi and Abedalaziz (2017) showed that work motivation positively affected teaching competence and ultimately improved teacher performance.

Despite the fact that studies related to teaching competence and teacher performance have been conducted widely (Nurhasni et al., 2020; Toha and Katoningsih, 2018; Purba, Rafiani and Ali, 2018; Amalia and Saraswati, 2018; Xu and Ye, 2014), however, to the best of author's knowledge, no study that specifically examines organizational learning, academic supervision and work motivation simultaneously 
as determinant factors that possibly improve teaching competence and teacher performance in Islamic educational institutions. Therefore, this study proposed a new structural model in constructing the causality between organizational learning, academic supervision and work motivation in affecting teaching competence and further implicated teacher performance in modern pesantren by formulating the following hypothesis.

\section{H1. Teaching competence positively affects teacher performance.}

Numerous studies found a strong relationship between teaching competence and teacher performance in Indonesia (Aji, Martono and Fakhruddin, 2019; Toha and Katoningsih, 2018; Sumantri and Whardani, 2017). For instance, Toha and Katoningsih (2018) found that teaching competence positively affected teacher performance. Meanwhile, Purba, Rafiani and Ali (2018) examined the effect of competence, organizational commitment and non-financial compensation and found that competence was the most determinant variable in enhancing teacher performance. Therefore, teacher performance is highly determined by their teaching competencies, including pedagogical, professional, social and personality competencies (Arifin, 2015). Amalia and Saraswati (2018) further showed that teachers with certification have a higher teaching competence and performance level than teachers without certification. Meanwhile, $\mathrm{Xu}$ and Ye (2014) stated that the academic climate also affected the relationship between competence and teaching performance. Finally, Nurhasni et al., (2020) specifically found that pedagogic competence and professional competence, which are the dimensions of teaching competence, positively affected teacher performance.

\section{H2. Organizational learning positively affects teaching competence}

\section{H3. Organizational learning positively affects teacher performance}

H4. Organizational learning positively affects teacher performance mediated by teaching competencies

Hartono et al., (2017) found that organizational learning positively affected teaching competence on lecturers in higher education simultaneously with the need for achievement and further affected their performance. Thus, organizational learning effectively improved teaching competence. Hartono et al., (2017) measure organizational learning through indicators of learning proactively, finding alternative methods, learning new knowledge, discussing the current issues and trying a different perspective on teaching. Goestjahjanti et al., (2020) and Putra et al., (2020) showed that organizational learning also improved soft skills, hard skills, and innovation capabilities, possibly making teachers ready to face the challenges and changes of teaching in the future. Furthermore, Hartono et al., (2017) empirically also proved that organizational learning affected teacher performance indirectly mediated by teaching competence. Hartono et al., (2017) stated that the mediation effect of teaching competence is greater than the direct effect of organizational learning on teacher performance. Therefore, teacher performance can be improved more effectively by organizational learning through increasing teaching competence. However, empirical research related to organizational learning and teaching competence in education is still rare, so further research is needed.

\section{H5. Academic supervision positively affects teaching competence}

\section{H6. Academic supervision positively affects teacher performance}

H7. Academic supervision positively affects teacher performance mediated by teaching competence

Academic supervision in education is a significant factor that can improve teaching competence (Saihu, 2020; Azwardi, 2020). Academic supervision focused on how the supervisor helped teacher problems in teaching (Saihu, 2020). Academic supervision has several functions, including inspection, assessment, training and coaching of teachers through a directive, collaborative, and instructive approach (Azwardi, 2020). However, the collaborative approach is considered more effective in implementing academic supervision to increase teaching competence (Azwardi, 2020). Meanwhile, Saihu (2020) argued that institutions must integrate it with total quality management (TQM) to achieve maximum academic supervision. Empirically, the previous research showed that academic supervision positively affected teacher competence (Karnati, 2019; Maritasari et al., 2020), including in Islamic educational institutions, despite the fact that it not implemented optimally (Huda, 2018). Besides, academic 
supervision was also effective in improving teacher performance (Hoque et al., 2020; Maritasari et al., 2020; Prasetyono, Abdillah and Fitria, 2018). Hariprasetya et al., (2016) showed that academic supervision and teaching competence are positively related to teacher performance. Kartini, Kristiawan and Fitria (2020) specifically viewed that academic supervision effectively improved teacher performance through the mediation of professional competence. Meanwhile, Mutohar and Trisnantari (2020) stated that academic supervision simultaneously with managerial capabilities and school organizational culture can enhance teacher performance and further enhance madrasas' effectiveness. Finally, (Rachman, 2020; Mujiyati, Suriansyah and Effendi, 2019) found that academic supervision can improve teachers' quality in teaching.

\section{H8. Work motivation positively affects teaching competence}

\section{H9. Work motivation positively affects teacher performance}

H10. Work motivation positively affects teacher performance mediated by teaching competence

Studies related to work motivation and teacher competence are also scarce. However, Abbas (2013) showed that intrinsic and extrinsic motivation positively affected teaching competence and subsequently affected teacher performance. Several studies have found that work motivation has a strong relationship with teaching competence in English as a foreign language (EFL) teachers (Boset, Asmawi and Abedalaziz, 2017), while the others stated that work motivation affected teacher competence in public schools (Pradja et al., 2018). Muhajirin, Prihatin and Yusuf (2017) specifically found that work motivation enhanced teacher professional competence. Otherwise, studies related to work motivation and performance have been widely conducted both in the education sector (Boset, Asmawi and Abedalaziz, 2017; Setiyaningsih, 2020; Andriani, Kesumawati and Kristiawan, 2018; Habibi, Raharjo and Rifa, 2018; Abbas, 2013), as well as in non-education sector (Makki and Abid, 2017; Kalhoro, Jhatial and Khokhar, 2017; Hendijani et al., 2016). For instance, Andriani, Kesumawati and Kristiawan (2018) found that work motivation affected teacher performance simultaneously with transformational leadership in vocational schools. In accordance with that, Setiyaningsih (2020) also found that principal leadership and work motivation significantly affected teacher performance, while the study by Habibi, Raharjo and Rifa (2018) showed that compensation, academic supervision, pedagogic competence and work motivation affected teacher performance in vocational schools. However, to the best of the authors' knowledge, similar research has not been widely conducted in Islamic educational institutions, especially in modern pesantren.

\section{METHODS}

This study was conducted at modern pesantren Ummul Quro Al-Islami, Bogor, West Java and collected data through a questionnaire distributed online using google-forms. This study involved 128 teachers selected through simple random sampling. We used six measurement scales consisted of organizational learning (5 items), academic supervision (5 items), Work Motivation (12 items), teaching competence (12 items) and teacher performance (5 items). Teacher performance is measured using a scale adapted from Maritasari et al., (2020), which consists of five indicators: planning of learning, utilizing instructional media, connecting students in various learning experiences, working with students exclusively, and active leadership of the teacher. Meanwhile, the teaching competency scale is developed based on Government Regulation No. 16 of 2007, which included pedagogical, personality, social, and professional competence dimensions.

Organizational learning is measured using a scale developed by Hartono et al., (2017) that integrated several concepts of Greenwood, Argyris and Schon (1997), Vegt and Bunderson (2005) and Sessa and London (2015). These Organizational learning indicators included learning proactively, finding alternative methods, learning new knowledge, discussing the current issues and trying a different perspective. Furthermore, the academic supervision scale is adopted from Maritasari et al., (2020), which consists of five indicators covering motivating the teacher, supervising learning activities, helping them determine subject materials, and giving them instructional direction as well as instructional tasks. 
Finally, work motivation is measured through a multidimensional work motivation scale developed by Gagné et al., (2015), consisting of amotivation, extrinsic social and material regulation, introjected and identified regulation, and intrinsic motivation.

All measurement used a Likert scale, ranging from 1 (strongly disagree) to 5 (strongly agree), specifically for teaching competence and teacher performance constructs, which consisted of several non-favourable items, the assessment conducted in reverse, ranging from 1 (strongly agree) to 5 (strongly disagree). Collected data then analyzed using structural equation modelling through partial least squares (SEM-PLS) with the help of Smart PLS to examine the causality relationship between latent variables. Ghozali and Latan (2019) stated that SEM-PLS analysis is a simultaneous equation focused on predictions to describe latent variables based on indicators. SEM-PLS analysis is conducted in two evaluation models, i.e., measurement model evaluation and structural model evaluation. Measurement model evaluation included assessment of validity and reliability, and structural model evaluation aimed to predict the relationship (causality model) between latent variables through the bootstrapping procedure (Ghozali and Latan, 2019).

\section{RESULTS}

\section{Respondent Characteristics}

In this study, we viewed respondent characteristic based on gender, educational background, age, work tenure and alumni status. Of the 128 respondents, 65 (50.8 per cent) are male and 63 ( 49.2 per cent) are female. In the term of educational background, 6.3 per cent of respondents have graduate or master's degree (S2), 46.1 per cent have bachelor's degree (S1), and 47 per cent are graduated from high school (MA). Furthermore, based on age, 31 (24 per cent) of them are under 20 years old, 71 (55.5 per cent) are between 21 and 30 years old, 22 (17.2 per cent) are between 31 and 40 years old, and 4 (3.1 per cent) are between 41 and 50 years old. Meanwhile, 50.8 per cent of respondents have been working in PM UQI for less than 5 years, 38.3 per cent for 6 to 10 years, 9.4 per cent for 11 to 15 years, and 1.6 per cent for 15 to 20 years. Finally, based on alumni status, 69.5 per cent of the respondents are PM UQI alumni, and 30.5 per cent of them are not PM UQI alumni.

Table 1. Respondent Characteristics

\begin{tabular}{lll}
\hline \multicolumn{1}{c}{ Characteristic } & N (128) & Percentage (100\%) \\
\hline Gender & 65 & $50,8 \%$ \\
Male & 63 & $49,2 \%$ \\
Female & & \\
Educational Background & 61 & $47,7 \%$ \\
High School (MA) & 59 & $46,1 \%$ \\
Bachelor (S1) & 8 & $6,3 \%$ \\
Master (S2) & & \\
Age & 31 & $24,2 \%$ \\
$<20$ Years & 71 & $55,5 \%$ \\
21-30 Years & 22 & $17,2 \%$ \\
31-40 Years & 4 & $3,1 \%$ \\
41-50 Years & & \\
Work Tenure & 65 & $50,8 \%$ \\
$<5$ Years & 49 & $38,3 \%$ \\
6-10 Years & 12 & $9,4 \%$ \\
11-15 Years & 2 & $1,6 \%$ \\
15-20 Years & & \\
A1 &
\end{tabular}

Alumni Status 


\begin{tabular}{lll}
\hline \multicolumn{1}{c}{ Characteristic } & N (128) & Percentage (100\%) \\
\hline Alumni of PM UQI & 89 & $69,5 \%$ \\
Non-alumni of PM UQI & 39 & $30,5 \%$ \\
\hline
\end{tabular}

\section{Measurement Model Evaluation}

Measurement model evaluation aimed to evaluate the validity and reliability of each indicator in the construct. Since indicators used in this study are reflective, the convergent validity is viewed based on the loading factor score $(\mathrm{n}>0.60)$ and the discriminant validity is viewed based on the Average Variance Extracted (AVE) score $(n>0.50)$. Meanwhile, the construct reliability is assessed based on composite reliability and Cronbach alpha score $(n>0.70)$. However, Cronbach alpha score $(n>0.60)$ is acceptable for certain studies in the process of construct development or explorative study (Ghozali and Latan, 2019).

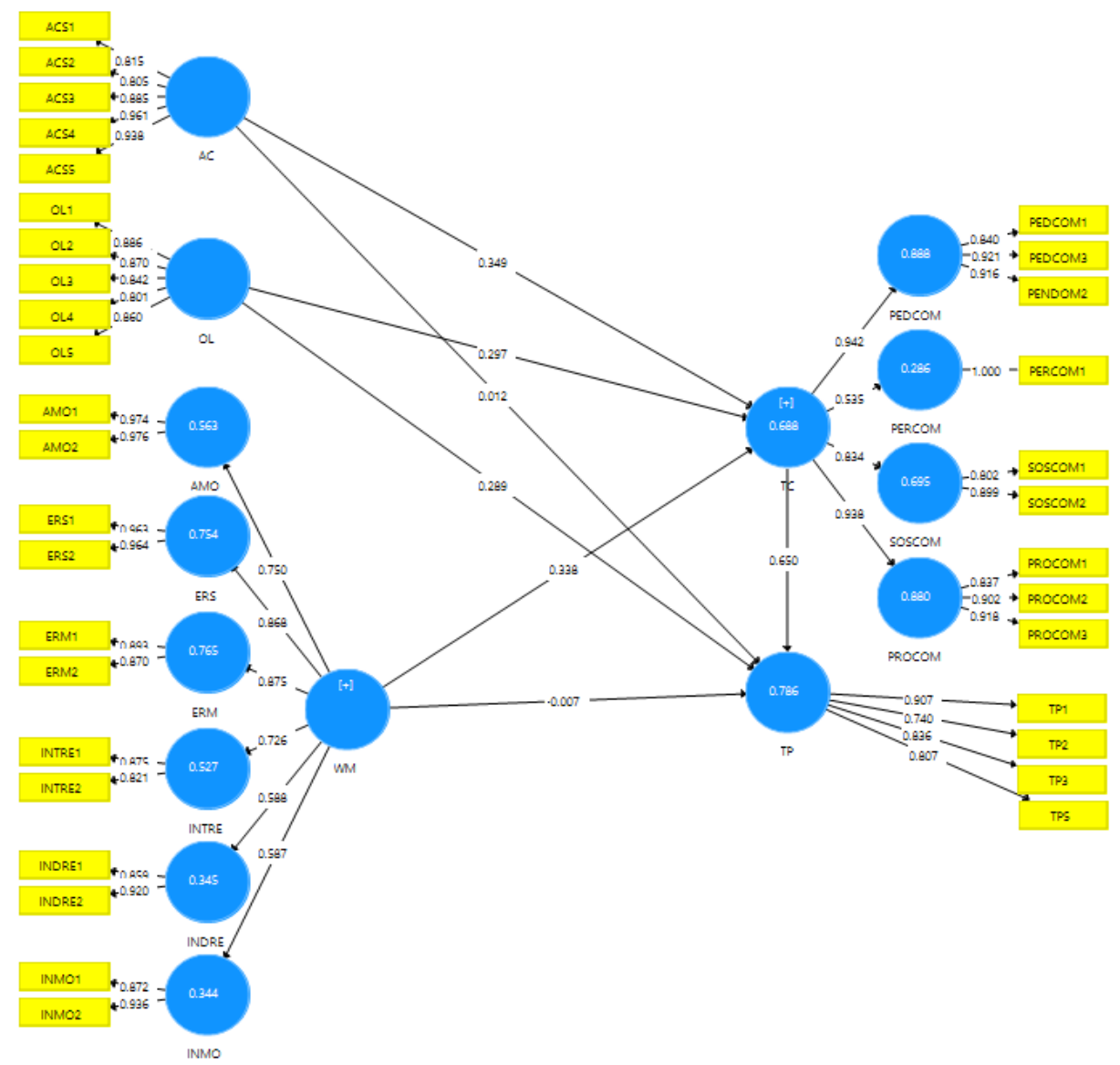

Figure 1. Factor Loading (Outer Model)

We dropped several indicators out in this measurement model evaluation that showed loading factor score below $<0.06$, including PERCOM1, PERCOM2, SOSCOM3, and TP4. Thus, the final result of the factor loading score is presented in Figure 1. Meanwhile, Table 2 shows The AVE, Cronbach alpha and Composite reliability score. 
Table 2. AVE, Cronbach Alpha and Composite Reliability

\begin{tabular}{llll}
\hline & $\begin{array}{c}\text { Average Variance } \\
\text { Extracted (AVE) }\end{array}$ & Cronbach's Alpha & Composite Reliability \\
\hline Organizational Learning & 0.727 & 0.906 & 0.930 \\
Academic Supervision & 0.780 & 0.928 & 0.946 \\
Work Motivation & 0.624 & 0.907 & 0.928 \\
Amotivation & 0.950 & 0.948 & 0.975 \\
Extrinsic Regulation-Material & 0.777 & 0.715 & 0.874 \\
Extrinsic Regulation-Social & 0.928 & 0.922 & 0.962 \\
Identified Regulation & 0.787 & 0.742 & 0.880 \\
Intrinsic Motivation & 0.801 & 0.783 & 0.889 \\
Interojected Regulation & 0.712 & 0.613 & 0.831 \\
Teaching Competence & 0.671 & 0.927 & 0.941 \\
Pedagogical Competence & 0.798 & 0.873 & 0.922 \\
Personality Competence & 1.000 & 1.000 & 1.000 \\
Professional Competence & 0.786 & 0.863 & 0.917 \\
Social Competence & 0.724 & 0.629 & 0.840 \\
Teacher Performance & 0.680 & 0.842 & 0.894 \\
\hline Structural Model Evaluation & & & \\
\hline
\end{tabular}

\section{Structural Model Evaluation}

The structural model firstly is evaluated through the R-Square score of the endogenous variable. The R-Square showed a predictive degree of certain exogenous variables toward endogenous variables. Based on the rule of thumb, the R-Square score below $0.25,0.50$ and 0.75 is categorized as a weak, moderate and strong model (Ghozali and Latan, 2019). Based on Table 3, the R-Square score for teaching competence is 0.672 , indicating that organizational learning, academic supervision, and work motivation explained 67.2 per cent of the variance in teaching competence. In contrast, 32.8 per cent explained by other variables. Meanwhile, the R-Square score for teacher performance is 0.800 , indicating that organizational learning, academic supervision, work motivation, and teaching competence simultaneously explained 80 per cent of the variance in teacher performance. In comparison, 29 per cent explained by other variables.

Table 3. Coefficient of Determination (R-Square)

\begin{tabular}{llll}
\hline & R Square & R Square Adjusted & \multicolumn{1}{c}{ Category } \\
\hline Teaching Competence & 0.672 & 0.664 & Strong \\
Teacher Performance & 0.800 & 0.794 & Highly Strong \\
\hline
\end{tabular}

The structural model further is evaluated based on coefficient $\beta$ and $t$-value (T-Statistic) through the bootstrapping procedure. Critical ratio scores greater than 1.96 showed the path coefficient is statistically significant at level $p<0.05$ (Ghozali and Latan, 2019). Based on Table 4, teaching competence positively and significantly affected teacher performance $(\beta=0.697$ and $t$-value $=7.515)$. Further, organizational learning also positively and significantly affected teaching competence $(\beta=0.285$ and $t$-value $=2.819)$ and teacher performance $(\beta=0.287$ and $t$-value $=3.464)$. Meanwhile, academic supervision has a positive and significant effect on teaching competence $(\beta=0.502$ and $t$-value $=5.532)$, but not on teacher performance $(\beta=-0.069$ and $t$-value $=0.779)$. Similar to academic supervision, work motivation also has a positive and significant effect on teaching competence $(\beta=0.151$ and $t$-value $=2.514)$, but not on teacher performance $(\beta=0.055$ and $t$-value $=1.176)$. This study also examined the indirect effects and found that organizational learning, academic supervision and work motivation affected teacher performance mediated by teaching competence. The coefficient $\beta$ and $t$-value in the mediation path between organizational learning and teacher performance are 0.199 and 2.377 , the coefficient $\beta$ and $t$-value in the mediation path between academic supervision and teacher performance are 0.350 
and 4.919, and the coefficient $\beta$ and $t$-value in the mediation path between work motivation and teacher performance are 0.105 and 2.115. Hence, all hypotheses in this study are accepted except for H6 and H9.

Table 4. Path Coefficient and T-Statistic Value (Hypothesis testing)

\begin{tabular}{lllll}
\hline \multicolumn{1}{c}{ Hypothesis } & \multicolumn{1}{c}{$\begin{array}{c}\text { Original } \\
\text { Sample }(\mathbf{O})\end{array}$} & $\begin{array}{c}\text { T Statistics } \\
(|\mathbf{O} / \mathbf{S T D E V}|)\end{array}$ & P Values & Conclusion \\
\hline Teaching Competence -> Teacher Performance & 0.697 & 7.515 & 0.000 & Accepted \\
Organizational Learning -> Teaching Competence & 0.285 & 2.819 & 0.005 & Accepted \\
Organizational Learning -> Teacher Performance & 0.287 & 3.464 & 0.001 & Accepted \\
Organizational Learning -> Teaching Competence & 0.199 & 2.377 & 0.018 & Accepted \\
-> Teacher Performance & & & & \\
Academic Supervision -> Teaching Competence & 0.502 & 5.532 & 0.000 & Accepted \\
Academic Supervision -> Teacher Performance & -0.069 & 0.779 & 0.437 & Rejected \\
Academic Supervision -> Teaching Competence & 0.350 & 4.919 & 0.000 & Accepted \\
-> Teacher Performance & & & & \\
Work Motivation -> Teaching Competence & 0.151 & 2.514 & 0.012 & Accepted \\
Work Motivation -> Teacher Performance & 0.055 & 1.176 & 0.240 & Rejected \\
Work Motivation -> Teaching Competence -> & 0.105 & 2.115 & 0.035 & Accepted \\
Teacher Performance & & & & \\
\hline
\end{tabular}

\section{DISCUSSION}

The objective of this study is to examine the effect of organizational learning, academic supervision and work motivation, which is perceived by teachers in modern pesantren, on their teaching competence and further implicated toward their performance. Additionally, to compare the effect of organizational learning, academic supervision and work motivation on teacher performance both directly and indirectly, this study also examined teaching competence as the mediator that linked those variables.

As expected, this study found that teaching competencies positively and significantly affected teacher performance in modern pesantren. The higher the teaching competence they possessed, the better the performance they exhibited. This finding is in accordance with previous studies conducted by Aji, Martono and Fakhruddin (2019), Toha and Katoningsih (2018), Sumantri and Whardani (2017). For instance, Purba, Rafiani and Ali (2018) examined the effect of competence, organizational commitment and non-financial compensation and found that competence was the most determinant variable in enhancing teacher performance. Therefore, teacher performance is highly determined by their teaching competencies, including pedagogical, professional, social and personality competencies (Arifin, 2015).

Furthermore, this study proved that organizational learning positively and significantly affected both teaching competence and teacher performance. The higher the level of organizational learning implemented in modern pesantren, the higher the level of teaching competence and teacher performance. In addition, this study also found that organizational learning positively and significantly affected teacher performance mediated by teaching competencies. These findings are consistent with previous studies conducted by Hartono et al., (2017), which found that organizational learning positively affected teaching competence on lecturers in higher education simultaneously with the need for achievement and further affected their performance. Hartono et al., (2017) empirically also proved that organizational learning affected teacher performance indirectly mediated by teaching competence.

Hartono et al., (2017) stated that the mediation effect of teaching competence is greater than the direct effect of organizational learning on teacher performance. That contrasted with our result, which found that the direct effect of organizational learning on teacher performance was more significant $(3,464)$ than the indirect effect through the mediation of teaching competence $(2,377)$. Thus, teachers' performance in modern pesantren is more effectively enhanced by organizational learning directly without considering their teaching competence. It is natural since organizational learning, which consisted of learning proactively, finding alternative methods, learning new knowledge, discussing the current issues, 
and trying a different perspective on teaching, can automatically increase their competence and further increase their performance.

Academic supervision was also found to affect teaching competence positively but not on teacher performance. First, the finding related to the positive effect of academic supervision on teaching competence supported previous studies (Saihu, 2020; Azwardi, 2020). Second, the finding showed the insignificant effect of academic supervision on teacher performance contrasted to previous research conducted by Hoque et al., (2020); Maritasari et al., (2020); Prasetyono, Abdillah and Fitria (2018). It possibly occurred due to the fact that academic supervision at PM UQI is not established directly by the principal or pesantren leaders. Instead, it conducted by particular teachers who are considered as the most competent ones in a specific subject.

However, this study found that academic supervision can improve teacher performance mediated by teaching competence. It indicated that academic supervision effectively improved teacher performance by increasing teaching competence. Without improving teaching competence, teacher performance in modern Islamic boarding schools cannot be improved through academic supervision. Thus, in this study, teaching competence is a full mediator that linked academic supervision and teacher performance. This finding supported the previous research conducted by Kartini, Kristiawan and Fitria (2020), who specifically viewed that academic supervision effectively improved teacher performance through the mediation of professional competence. However, according to Huda (2018), academic supervision of Islamic educational institutions is not implemented optimally. Therefore, institutions must integrate it with total quality management (TQM) to achieve maximum academic supervision (Saihu, 2020).

Similar to academic supervision, this study also found that work motivation has a positive and significant effect on teaching competence but not on teacher performance. The higher the teachers' work motivation in modern pesantren, the higher the teaching competence they possess. It's in line with previous studies (Boset, Asmawi and Abedalaziz, 2017; Pradja et al., 2018; Muhajirin, Prihatin and Yusuf, 2017). Conversely, the level of teacher performance in modern pesantren cannot be determined by their level of work motivation. Again, this finding contradicted previous studies (Setiyaningsih, 2020; Habibi, Raharjo and Rifa, 2018; Andriani, Kesumawati and Kristiawan, 2018). It possibly occurred due to models, cultural, education system differences adopted by modern pesantren, considering several studies cited above is conducted in general educational institutions, and not pesantren-based educational institutions.

After all, this study further found that work motivation effectively enhanced teacher performance mediated by teaching competence. It indicated that work motivation was less effective in enhancing teacher performance without increasing teaching competence. Thus, teaching competence is also a full mediator that linked work motivation and teacher performance in modern pesantren. This finding proved the initial study found by Abbas (2013), who said that intrinsic motivation and extrinsic motivation positively affected teaching competence and subsequently affected their performance.

\section{CONCLUSION}

Similar to previous studies, this study concluded that teaching competence effectively improved teacher performance in modern pesantren. Organizational learning also effective in enhancing teaching competence and teacher performance. Otherwise, academic supervision and work motivation only effective in enhancing teaching competence but less effective in enhancing teacher performance. This study also examined the indirect effect and found that organizational learning, academic supervision and work motivation effectively improved teacher performance in modern pesantren through the mediation of teaching competence.

Teacher performance is one of the most determinant factors in improving educational institution quality, including modern pesantren (Rahmah et al., 2020; Rahman et al., 2019; Kartini, Sujanto and Mukhtar, 2017). On the other hand, teacher performance is also greatly influenced by teaching competence (Nurhasni et al., 2020; Aji, Martono and Fakhruddin, 2019; Toha and Katoningsih, 2018; Sumantri and 
Whardani, 2017). Therefore, modern pesantren need to improve their teachers' teaching competence and performance. Based on the results of this study, teaching competence and teacher performance can be improved through organizational learning, academic supervision and work motivation. Organizational learning, for instance, will effectively encourage teachers to learn proactively, try new methods in the process of learning, and sharing knowledge among them. Meanwhile, academic supervision implemented in modern pesantren can be maximized by integrating it with total quality management (TQM). Finally, pesantren also needed to notice teachers' work motivation from various aspects, such as their need for intrinsic or extrinsic motivation.

Every research has limitations, including this study. One is related to the data collection method that was conducted online with a cross-sectional design approach. Future researchers are expected to collect data directly to increase data validation and accuracy, also possibly observe respondent's behaviour. In addition, further study is recommended to use a longitudinal study design to understand better causality between variables. Since this study only explored particular factors that were possibly enhancing teaching competence and teacher performance, i.e., organizational learning, academic supervision and work motivation, future research can review other variables such as job satisfaction, organizational commitment, work engagement, OCB, etc.

\section{REFERENCE}

Abbas, Y. (2013) 'Motivasi Intrinsik, Motivasi Ekstrinsik, Kompetensi Dan Kinerja Guru', HUMANITAS: Indonesian Psychological Journal, 10(1), p. 61. doi: 10.26555/humanitas.v10i1.329.

Aji, A. P., Martono, S. and Fakhruddin (2019) 'The Effect of Teacher Motivation in Mediating Commitment and Professional Competence on Teacher 's Performance of Vocational School in Blora Regency', Educational Management, 8(2), pp. 150-156.

Amalia, L. and Saraswati, T. (2018) 'The Impact of Competencies Toward Teacher's Performance Moderated By the Certification in Indonesia', KnE Social Sciences, 3(10), pp. 86-98. doi: 10.18502/kss.v3i10.3363.

Andriani, S., Kesumawati, N. and Kristiawan, M. (2018) 'The influence of the transformational leadership and work motivation on teachers performance', International Journal of Scientific and Technology Research, 7(7), pp. 19-29.

Azwardi (2020) 'Efforts To Improve Teacher Competency In Developing Learning Materials Through Collaborative Academic Supervision', Indonesian Education Administration and Leadership Journal (IDEAL), 2(1), pp. $1-12$.

Boset, S., Asmawi, A. and Abedalaziz, N. (2017) 'The Relationship between Competency and Work Motivation of EFL Teachers at Public Secondary Schools in Yemen', Arab World English Journal, 8(4), pp. 212-228. doi: 10.24093/awej/vol8no4.14.

EMIS | Dashboard | Pendis Kemenag (no date). Available at: http://emispendis.kemenag.go.id/ dashboard/?content=data-pontren\&action=lbg_detil\&prop=32\&k=01\&id=51\&nss=510032010969 (Accessed: 12 February 2021).

Falout, J. (2010) 'Strategies for teacher motivation', The Language Teacher, 34(6), p. 27. doi: 10.37546/jalttlt34.6-4.

Gagné, M. et al. (2015) 'The Multidimensional Work Motivation Scale: Validation evidence in seven languages and nine countries', European Journal of Work and Organizational Psychology, 24(2), pp. 178-196. doi: 10.1080/1359432X.2013.877892.

Ghozali, I. and Latan, H. (2019) Partial least squares konsep, teknik dan aplikasi menggunakan program smartpls 3.0 untuk penelitian empiris. Semarang: Badan Penerbit UNDIP.

Goestjahjanti, F. S. et al. (2020) 'Pengaruh Organizational Learning Terhadap Peningkatan Hard Skills, Soft Skills Dan Inovasi Guru', EduPsyCouns: Journal of Education, Psychology and Counseling, 2(1), pp. 87-97. Available at: https://ummaspul.e-journal.id/Edupsycouns/article/view/436.

Good, T. L. and Lavigne, A. L. (2015) 'Problemas de estabilidade de desempenho dos professores não são novos: Limitações e possibilidades', Education Policy Analysis Archives, 23(January). doi: 10.14507/epaa.v23.1916.

Goodwin, B. and Slotnik, W. J. (2019) 'Debunking the myth of the teacher performance plateau', Phi Delta Kappan, 100(7), pp. 56-61. doi: 10.1177/0031721719841340.

Greenwood, D. J., Argyris, C. and Schon, D. A. (1997) 'Organizational Learning II: Theory, Method, and Practice.', Industrial and Labor Relations Review, 50(4), p. 701. doi: 10.2307/2525281. 
Habibi, B., Raharjo, T. J. and Rifa, A. (2018) 'The Journal of Educational Development The Influence of Compensation, Academic Supervision, Pedagogic Competency, and Work Motivation on the Performance of Business and Management Teachers', 6(1), pp. 16-24.

Hariprasetya, A. et al. (2016) 'The relationship of academic supervision, educational profession insentive and teacher competence with teacher performance at the performing middle schools in Malange, East Java, Indonesia', Journal of Social Sciences (COES\&RJ-JSS), 5(4), pp. 595-605. doi: 10.25255/jss.2016.5.4.595.605.

Hartiwi, H., Kozlova, A. Y. and Masitoh, F. (2020) 'the Effect of Certified Teacher and Principal Leadership Toward Teachers' Performance', International Journal of Educational Review, 2(1), pp. 70-88. doi: 10.33369/ijer. v2i1.10629.

Hartono, E. et al. (2017) 'Does Organizational Learning Affect the Performance of Higher Education Lecturers in Indonesia? The Mediating Role of Teaching Competence.', International Journal of Environmental and Science Education, 12(4), pp. 865-878.

Hendijani, R. et al. (2016) 'Intrinsic motivation, external reward, and their effect on overall motivation and performance', Human Performance, 29(4), pp. 251-274. doi: 10.1080/08959285.2016.1157595.

Hoque, K. E. et al. (2020) 'Relationships Between Supervision and Teachers' Performance and Attitude in Secondary Schools in Malaysia’, SAGE Open, 10(2). doi: 10.1177/2158244020925501.

Huda, S. (2018) 'Academic Supervision of Madrasah Supervisors in Improving Professional Competencies of Teachers', Ta'dib:Journal of Islamic Education (Jurnal Pendidikan Islam), 23(2), pp. 155-163. doi: 10.19109/ tjie.v23i2.2570.

Hutagalung, D. et al. (2020) 'Peran Religiusitas, Kepemimpinan Transformasional, Kepuasan Kerja dan Mediasi Organizational Citizenship Behavior terhadap Kinerja Guru’, EduPsyCouns: Journal of Education, Psychology and Counseling, 2(1), pp. 311-326. Available at: https://ummaspul.e-journal.id/Edupsycouns/ article/view/483.

Kalhoro, M., Jhatial, A. A. and Khokhar, S. (2017) 'Investigating the Influence of Extrinsic and Intrinsic Motivation on Work Performance: Study of Bank Officers', Journal Gmjacs, 7(1), pp. 121-129. Available at: http:// gmjacs.bahria.edu.pk/wp-content/uploads/2017/08/Volume-7-Number-1-10.pdf.

Karnati, N. (2019) 'Academic Supervision To Improve The Competence Of Elementary School Teachers', Australasian Journal of Educational Technology, 35(1), pp. 36-46.

Kartini, D., Kristiawan, M. and Fitria, H. (2020) 'The Influence of Principal's Leadership, Academic Supervision, and Professional Competence toward Teachers' Performance', International Journal of Progressive Sciences and Technologies (IJPSAT) ISSN: 2509-0119., 20 No. 1 A(April), pp. 156-164.

Kartini, K., Sujanto, B. and Mukhtar, M. (2017) 'The influence of organizational climate, transformational leadership, and work motivation on teacher job performance', IJHCM (International Journal of Human Capital Management), 1(01), pp. 192-205. doi: 10.21009/ijhcm.01.01.15.

Lie, D. et al. (2020) 'The Impact of Work Discipline and Work Ethic on the Teacher Performance of Sultan Agung Pematangsiantar Private Middle School Teachers T.A. 2018/2019', International Journal of Business Studies, 3(3), pp. 125-135. doi: 10.32924/ijbs.v3i3.83.

Mailool, J. et al. (2020) 'Synthesis and detection of publication bias in relationship between motivation and teacher performance: A meta-analysis review’, Universal Journal of Educational Research, 8(11B), pp. 6208-6216. doi: 10.13189/ujer.2020.082259.

Makki, A. and Abid, M. (2017) 'Influence of Intrinsic and Extrinsic Motivation on Employee's Task Performance', Studies in Asian Social Science, 4(1), p. 38. doi: 10.5430/sass.v4n1p38.

Makruf, I. (2017) 'Leadership Model in Integrated Islamic Educational Institutions', Jurnal Pendidikan Islam, 6(2), p. 331. doi: 10.14421/jpi.2017.62.331-348.

Maritasari, D. B. et al. (2020) 'The effect of training and supervision on teacher performance through teacher competence as a mediating variable in primary schools', Universal Journal of Educational Research, 8(11 C), pp. 105-112. doi: 10.13189/ujer.2020.082312.

Measures, P. (2016) 'Key Elements Key Elements', (March), pp. 1-3.

Mesiono, M. (2019) 'The Influence of Job Satisfaction on the Performance of Madrasah Aliyah (Islamic Senior High School) Teachers', Tadris: Jurnal Keguruan dan Ilmu Tarbiyah, 4(1), pp. 107-116. doi: 10.24042/ tadris.v4i1.4388.

Muhajirin, Prihatin, T. and Yusuf, A. (2017) 'Pengaruh Supervisi Akademik dan Partisipasi Guru pada MGMP Melalui Motivasi Kerja Terhadap Profesionalisme Guru SMA / MA’, Educational Management, 6(2), pp. 170-177. 
Muhammad Arifin, H. (2015) 'The influence of competence, motivation, and organisational culture to high school teacher job satisfaction and performance’, International Education Studies, 8(1), pp. 38-45. doi: 10.5539/ies. v8n1p38.

Muhammadi, N., Marzuki, S. C. bin H. and Hussin, M. Y. bin M. (2015) 'The Madrasah Leadership, Teacher Performance and Learning Culture to Improve Quality at Madrasah Tsanawiyah Negeri Jakarta of South', Journal of Management and Sustainability, 5(2), pp. 129-145. doi: 10.5539/jms.v5n2p129.

Mujiyati, Suriansyah, A. and Effendi, R. (2019) 'Effect of Academic Supervision and School Culture on Teacher's Teaching Quality in Public Islamic Senior High School Banjarmasin', Journal of K6, Education, and Management, 2(2), pp. 126-132. doi: 10.11594/jk6em.02.02.07.

Murtiningsih, Kristiawan, M. and Lian, B. (2019) 'The Correlation Between Supervision of Headmaster and Interpersonal Communication', European Journal of Education Studies, 6(1), pp. 246-256. doi: 10.5281/ zenodo.2649535.

Mutohar, P. M. and Trisnantari, H. E. (2020) 'The effectiveness of madrasah: Analysis of managerial skills, learning supervision, school culture, and teachers' performance', Malaysian Online Journal of Educational Management, 8(3), pp. 21-47. doi: 10.22452/mojem.vol8no3.2.

Nasution, N. W. (2018) 'The effectiveness of teachers' performance of islamic junior high school in islamic boarding school langkat district, indonesia', Jurnal Ilmian Peuradeun, 6(2), pp. 325-338.

Nurhasni, L. et al. (2020) 'the Effect of Pedagogic Competency and Competence on Professional Teacher Performance in Padang Pariaman Regency Private Vocational School', International Journal of Engineering Technologies and Management Research, 6(7), pp. 52-62. doi: 10.29121/ijetmr.v6.i7.2019.415.

Pradja, N. S. et al. (2018) 'Analysis of teacher competence social studies', 15(2). doi: 10.25134/equi.v15i02. Abstract.

Prasetyono, H., Abdillah, A. and Fitria, D. (2018) 'Academic Supervision toward Teacher's Performance through Motivation as Intervening Variable', Journal of Education and Learning (EduLearn), 12(2), p. 188. doi: 10.11591/edulearn.v12i2.7324.

Purba, C. B., Rafiani and Ali, H. (2018) 'The Influence of Competency, Organizational Commitment and Non Financial Compensation on Teacher Performance in SMAN 29 Jakarta', Scholars Journal of Economics, Business and Management (SJEBM), pp. 227-239. doi: 10.21276/sjebm.2018.5.3.13.

Putra, A. S. et al. (2020) 'Examine Relationship of Soft Skills, Hard Skills, Innovation and Performance: the Mediation Effect of Organizational Learning', International Journal of Science and Management Studies (IJSMS), 3(3), pp. 27-43. Available at: http://www.ijsmsjournal.org/2020/volume-3 issue-3/ijsms-v3i3p104. pdf.

Rachman, A. A. (2020) 'Improving the Quality of Learning Through Academic Supervision (Study in SMP Negeri 14 Banjarbaru)', The Innovation of Social Studies Journal, 2(1), p. 10. doi: 10.20527/iis.v2i1.2306.

Rahmah, M. et al. (2020) 'The Effect of Islamic Work Ethic Towards Teacher Performance With Work Motivation as an Intervening Variable at Sabilillah Islamic Boarding School in Sampang', 456(Bicmst), pp. 29-32. doi: 10.2991/assehr.k.201021.007.

Rahman, A. et al. (2019) 'Madrasah Principal and Organizational Culture on Teacher Performance At Pesantren Muhammadiyah in South Sulawesi', International Journal of Social Sciences, 77(1), pp. 1-15.

Renata, Wardiah, D. and Kristiawan, M. (2018) 'The influence of headmaster's supervision and achievement motivation on effective teachers', International Journal of Scientific and Technology Research, 7(6), pp. $44-49$.

Saihu (2020) 'The Urgency Of Total Quality ... The Urgency Of Total Quality ...', 09(02), pp. 19-44.

Sessa, V. and London, M. (2015) 'Continuous learning in organizations: Individual, group, and organizational perspectives'. Available at: https://books.google.com/books

Setiyaningsih, T. T. (2020) 'Influence of school leadership, discipline, and work motivation toward high school teacher performance', Harmoni Sosial: Jurnal Pendidikan IPS, 7(1), p. 65. doi: 10.21831/hsjpi.v7i1.13423.

Steinberg, M. P. and Kraft, M. A. (2017) 'The Sensitivity of Teacher Performance Ratings to the Design of Teacher Evaluation Systems', Educational Researcher, 46(7), pp. 378-396. doi: 10.3102/0013189X17726752.

Sumantri, M. S. and Whardani, P. A. (2017) 'Relationship between Motivation to Achieve and Professional Competence in the Performance of Elementary School Teachers', International Education Studies, 10(7), p. 118. doi: 10.5539/ies.v10n7p118.

Toha, M. and Katoningsih, S. (2018) 'The effect of leadership, organizational culture, and competency on teachers' performance in Ibu Kartini vocational high school Semarang', AIP Conference Proceedings, 1941, pp. 1-4. doi: $10.1063 / 1.5028102$. 
Ulfaa, M. and Irawan (2018) 'Manajemen Ustaz dan Ustazah di Pesantren Modern', Madrasa: Jurnal of Islamic Educational Management, 1(2), pp. 1-8. Available at: https//doi.org/10.32940/mjiem.v1i0.1\%0AOpen.

Van Der Vegt, G. S. and Stuart Bunderson, J. (2005) 'Learning and performance in multidisciplinary teams: The importance of collective team identification', Academy of Management Journal. Academy of Management, pp. 532-547. doi: 10.5465/amj.2005.17407918.

verawati, rika (2016) 'Pengaruh Kepemimpinan, Motivasi Kerja Dan Komitmen Kerja Terhadap Kinerja Guru Madrasah Aliyah Negeri (Man) Lubuk Alung', Economica, 4(2), pp. 304-316. doi: 10.22202/economica. v4i2.650.

$\mathrm{Xu}, \mathrm{A}$. and Ye, L. (2014) 'Impacts of teachers' competency on job performance in research universities with industry characteristics: Taking academic atmosphere as moderator', Journal of Industrial Engineering and Management, 7(5), pp. 1283-1292. doi: 10.3926/jiem.1261.

Yahya, F. A. (2015) 'Problem Manajemen Pesantren, Sekolah, Madrasah: Problem Mutu Dan Kualitas', elTarbawi, VIII(1), pp. 93-116. 